\title{
Black Soldier Fly: A New Vista for Waste Management and Animal Feed
}

\author{
S.N. Rindhe*, Manish Kumar Chatli, R.V. Wagh, Amanpreet Kaur, \\ Nitin Mehta, Pavan Kumar and O.P. Malav \\ Department of Livestock Products Technology \\ Guru Angad Dev Veterinary and Animal Sciences University, Ludhiana, India \\ *Corresponding author:
}

\section{A B S T R A C T}

The newest waste management technology is bioconversion using fly larvae converting

\section{Keywords}

Black soldier fly and Waste management

Article Info

Accepted:

10 December 2018

Available Online:

10 January 2019 organic waste to insect larval biomass and organic residue. Bioconversion is a practice of recovering resources while simultaneously limiting the amount of organic material affecting landfill behaviour. Several organisms have been used in this treatment process. Several studies have been done using the black soldier fly larvae to degrade organic material. Most of these studies focused on the degradation of cow, chicken or pig manure by Hermetia illucens larvae in cost- and maintenance-intensive systems of developed countries. Undoubtedly, organic waste continues to cause several problems in developing countries, as no valid solution has yet been identified. Development from experimental to full-scale waste treatment facilities, using the larvae of the black soldier fly, offers several advantages. Since such facilities can be developed and operated at low cost (low building and maintenance costs; independent from power supply), they are more adapted to the economic potential of developing countries. This paper presents future areas of research and collected information is expected to open new avenues for a large scale use of insect for management of waste.

\section{Introduction}

Urban solid waste management is considered one of the most immediate and serious environmental problems confronting urban governments in low- and middle-income countries. The severity of this challenge will increase in the future onus to the trends of rapid urbanisation and growth of urban population. Due to growing public pressure and environment concerns, waste experts worldwide are formulating to develop efficient and sustainable methods of utilization of municipal waste that embrace the concept of a circular economy. Recycling organic waste material (bio-waste) is still fairly limited, especially in low- and middle-income settings, although this is by far the largest fraction of all generated municipal waste. The present paper describes the fairly novel approach of bio-waste conversion by insect larvae, using the example of the Black Soldier Fly (BSF), Hermetia illucens, However, academic publications on BSF are limited might be due to the business interest and perceived need to maintain a competitive edge Hence, the 
practical day-to-day working steps required to operate such a facility is still lacking. The popularity of this competitive low-cost technology is on the rise. Therefore, this publication aims to introduce the technology to Indian farmers and provide the practical benefits over and above the existing waste utilization methods. Further, the author describes the nutritional benefits of the BSF larvae feeding to animals and birds. Filling this gap is the main objective of this publication. Upscaling or transferring this information to a larger facility might require some adaptation or adjustment of equipment. It is, however, our opinion that the standard procedures described are valid for a large range of scaling-up. It has drawn attention of scientist for its dual effect of waste utilization and use of BSF larvae as protein source in feed especially poultry. The small farmers especially in Thailand, Malaysia backyard poultry growers are using this low-cost technology, efficiently. India is producing more than 10 MT of organic waste including fruits, vegetables and meat industry. However, not more than 15-25\% total agro-processing waste is being utilized.

\section{The black soldier fly}

The black soldier fly (Hermetia illucens Linnaeus) is a member of the Stratiomyidae family. The adult fly is wasp-like and 15-20 $\mathrm{mm}$ long (Hardouin et al., 2003). Primarily black, the female's abdomen is reddish at the apex and has two translucent spots on the second abdominal segment.

The male's abdomen is somewhat bronze in color. H. illucens is native to the tropical, subtropical and warm temperate zones of America, but during World War II they spread into Europe, Asia, including India, and even to Australia. The development of international transportation since the 1940s has resulted in its naturalisation in many regions of the world (Leclercq, 1997). It is now widespread in tropical and warmer temperate regions (Diener et al., 2011), breeding in compost, manure and outdoor toilets. The flies can be seen in bright sunlit areas, resting on nearby structures or vegetation.

They are generally considered a beneficial insect and non pest. The adult fly does not have mouthparts and doesn't even feed during its short lifespan. They do not bite or sting, feed only as larvae, and are not associated with disease transmission. Black solider flies make breeding areas of houseflies less desirable. The fly is often associated with the outdoors and livestock, usually being found around decaying organic matter such as animal waste or plant material. Adult flies are easily distinguished by their long antennae (Gennard, 2012). Black soldier flies are an extremely resistant species capable of dealing with demanding environmental conditions, such as drought, food shortage or oxygen deficiency (Diener et al., 2011) (Table 1-3).

\section{Larva as bio-converter}

Rearing $H$. illucens has been proposed as an efficient way todispose of organic waste, by converting them into a proteinand fat-rich biomass suitable for various purposes, including animal feeding for all livestock species, biodiesel and chitin production (Van Huis et al., 2013; Diener et al., 2011; Li et al., 2011). These have been used to reduce animal manure in commercial swine and poultry facilities in western countries, but in India the practice is not common. BSFL can convert around $58 \%$ of the dry matter within an organic source into high quality animal feedstuff (Sheppard et al., 1994). There is a good opportunity to utilise these flies for bioconversion considering the fact that approximately 1.3 billion tonnes of food is wasted from the food produced each year in world (Gustavsson et al., 2011) (Table 4, 5 and 6). 


\section{BSF life cycle}

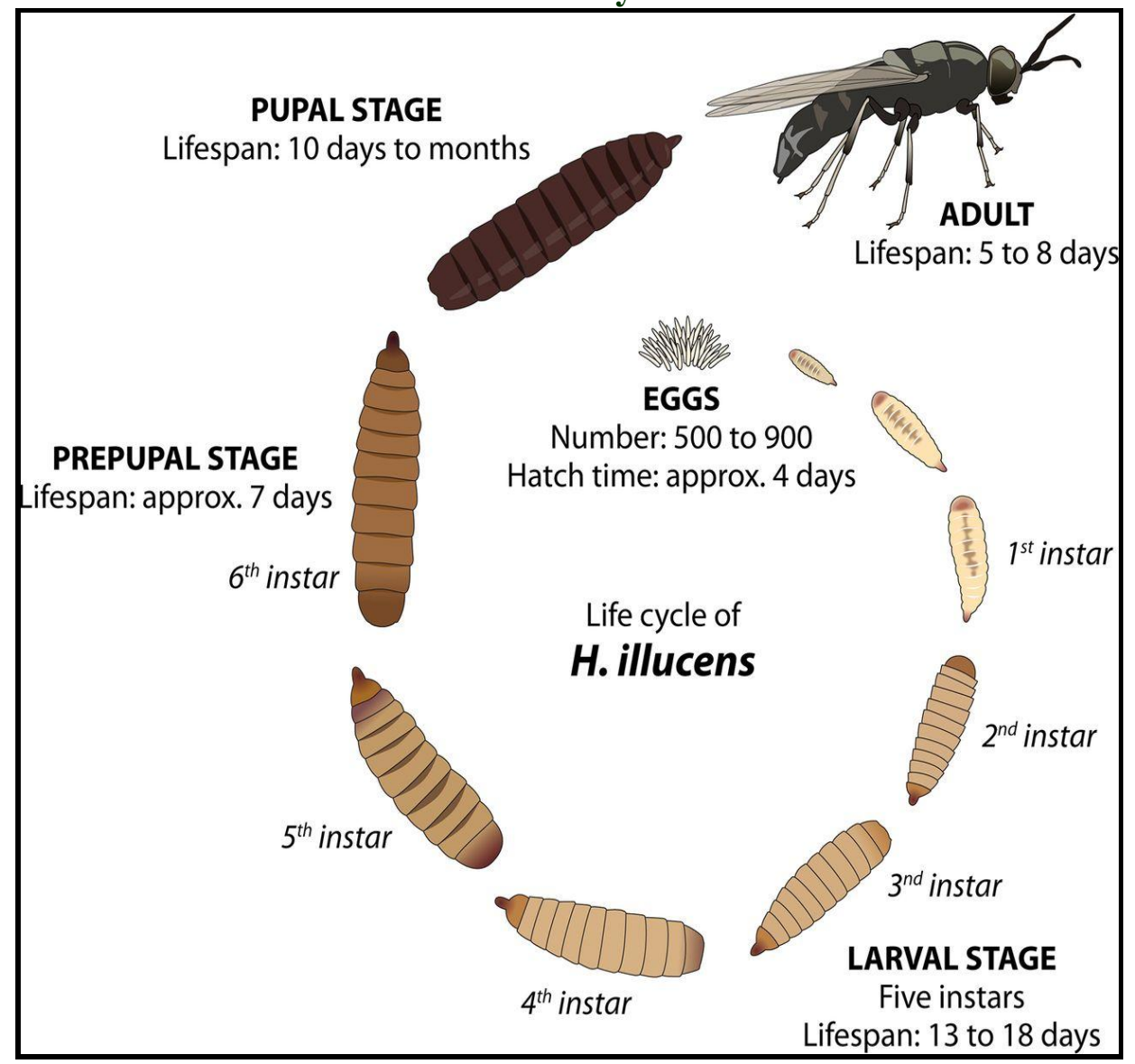

(Source: St-Hilaire et al., 2007)

The larvae convert organic waste material faster than worms used in vermicomposting. A colony of 2,000 larvae can consume about a $\mathrm{kg}$ of house hold food waste per day. They have large and powerful chewing mouthparts and hence are able to consume organic compounds before they have time to decompose, thereby immediately eliminating odor. Additionally, the larvae modify the microflora of manure, potentially reducing harmful bacteria such as Escherichia coli 0157:H7 and Salmonella enterica (Van Huis et al., 2013). It has been reported that the larvae contain natural antibiotics which act on growth promoter in the animal feed (Newton et al., 2008). In addition to the larvae, the residue or castings which are obtained during larval rearing under controlled conditions can be used for soil amendment.

\section{Salient features}

Waste biomass is converted into larvae and residue. The larvae consist of $\pm 35 \%$ protein and $\pm 30 \%$ crude fat. This insect protein is of high quality and is an important feed resource for chicken and fish farmers. Feed trials have confirmed it as being a suitable alternative to fish meal.

Feeding waste to larvae has been shown to inactivate disease transmitting bacteria, such as Salmonella spp. This implies that the risk of disease transmission between animals and between animals and humans is reduced when using this technology at farm level or when treating waste of animal origin in general (e.g. chicken manure or slaughterhouse waste). However, risk reduction is achieved mainly 
through material reduction $( \pm 80 \%)$ rather than through pathogen inactivation.

Waste reduction of up to $80 \%$ on wet weight basis has been demonstrated. If treatment is applied at the source of bio-waste generation, the costs for waste transport and space requirements for landfills can, thus, be reduced drastically. Such organic waste treatment could furthermore reduce open dumping, which is still an unfortunate reality in low- and middle-income settings.
The residue, a substance similar to compost, contains nutrients and organic matter and, when used in agriculture, helps to reduce soil depletion.

A high waste-to-biomass conversion rate of up to $25 \%$ on wet weight basis.

There is no need for sophisticated high-end technology to operate, so it is suitable for lowincome groups without skill labours.

\section{Layout of a BSF treatment facility (Two tons of Bio-waste per day)}

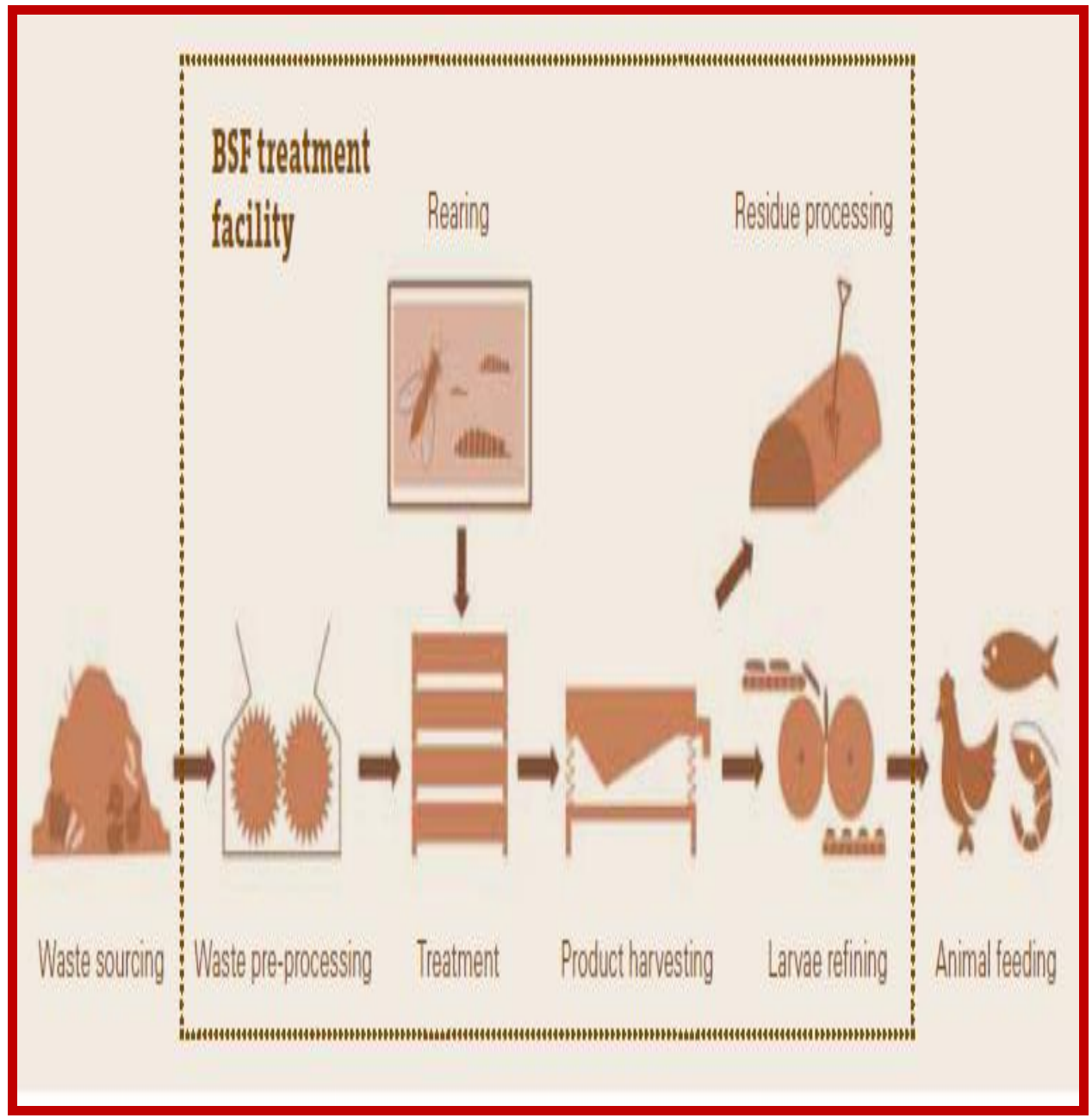

(Source: St-Hilaire et al., 2007) 

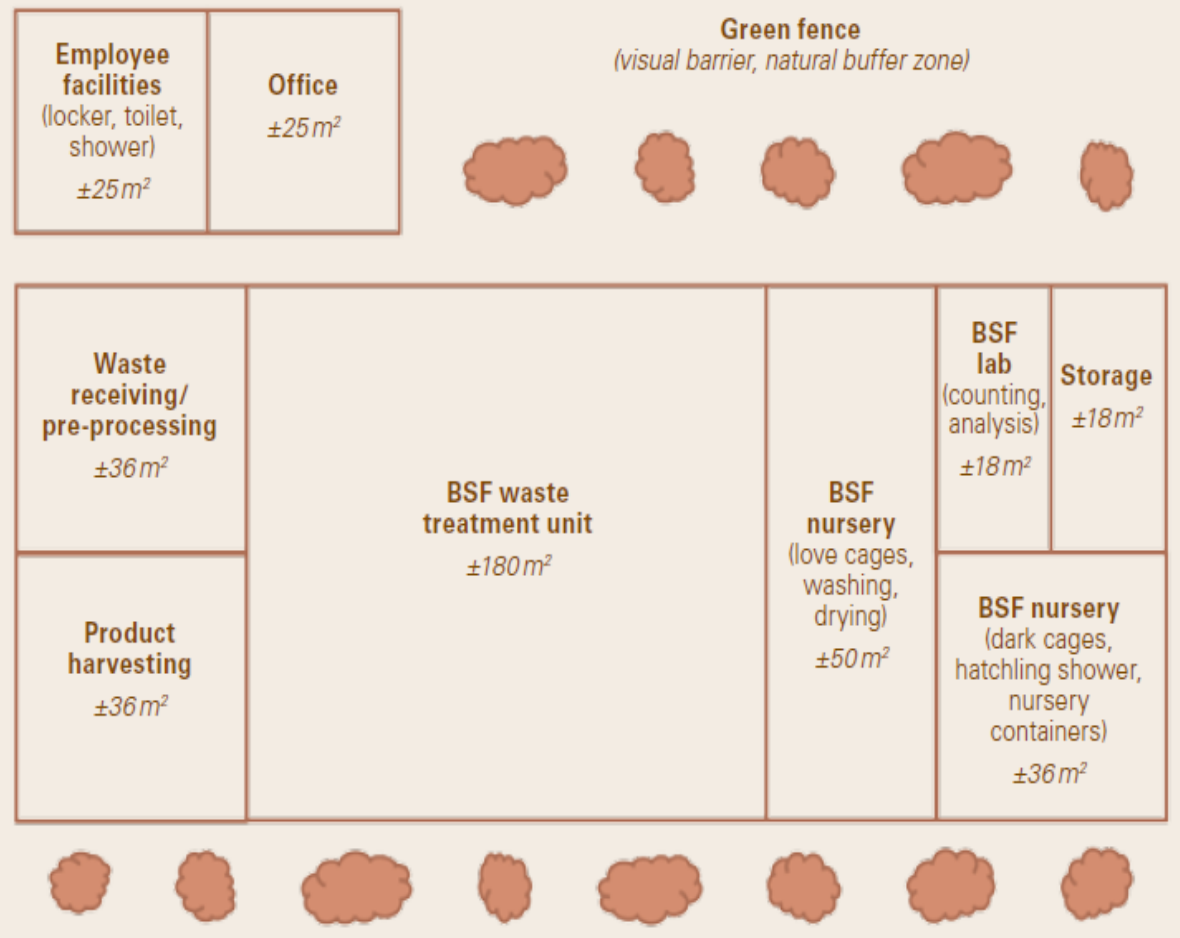

(Source: St-Hilaire et al., 2007)

The economic viability of a BSF processing facility will depend on following local conditions

Scale and respective capital and operating costs of the facility

Climate (temperature, humidity)

Potential revenue from waste processing (tipping fees)

Sales revenue from larvae derived products (e.g. whole larvae, protein meal, larval oil, etc.)

Sales of the waste residue as soil amendment or its use in a biogas plant.

\section{General benefits}

The potential financial benefits of this program are many, and can be locally or widely distributed. Primarily there are environmental benefits to valorizing the large volume of organics currently underutilized. In addition, the aquaculture and livestock industries can benefit by locally sourced cost competitive alternate protein meals. Greenhouse and vegetable production industries can achieve a double benefit, through an outlet for organics waste and return of high quality growing medium to enhance plant growth and health. The high value market products both lend themselves to pelleting, which enables economic delivery to a wider market, should production exceed local market demand, which is unlikely within India. Additionally, potential health benefits may be derived from what would be a natural feed ingredient for free range poultry and fish, from the ideal nature of the amino acids, possible antimicrobial peptides and natural chitins. In terms of further sustainability of the agriculture industry, vegetable wastes left in fields represent leachate and contamination of the environment and so must be hauled away to disposal sites, and it has proved very difficult to find alternative methods of nutrient management. Similarly to composting this 
leaves large problematic volumes of liquid waste for disposal post digestion. The larval growth model provides for many of these issues providing nutrient recycling, reduction, and value add, all significant contributions to the economic viability, competitiveness and strategic development of the horticulture and greenhouse industries. An over-riding benefit of this project to the Province would be the potential development of a new "value add" industry to service existing bio-product markets, allowing enhanced competitiveness and potential expansion of other primary industries. All these benefits revolve around the core benefit of removing organic wastes from the landfill and disposal systems, freeing up space, potentially saving large amounts of costs on transportation, while providing much higher value add end products.

\section{Environmental benefits}

Black soldier flies are also known to reduce the mass and nutrient content of swine manure at efficiencies similar to poultry manure, with benefits for improved farm hygiene, reduced pest fly populations, and reduced nutrient pollution in runoff. Although the flies would not be produced in sufficient volumes to feed the swine, they can be redirected to other uses such as fish feed, and the remaining manure residue used for horticulture, enabling plants to grow in otherwise low-quality soils or even sand. BSFL can be reared on dairy cow manure, which is often mixed with other materials to improve larval yields and total waste reduction due to the high crude fiber content of pure dairy manure that the flies otherwise cannot fully digest. BSFL can also be reared on slaughterhouse blood and offal, again valorizing wastes from human food production. It is therefore well established that BSFL can be used to feed many vertebrates and can use various vertebrate wastes as a substrate, with no effects on the palatability of the BSFL-fed meats for humans and with significant implications for sustainable and lower-input agriculture in the developing world. While the potential benefits are greatest in these developing nations, BSFL and other insect feeds are expected to play larger roles over time in advanced economies such as the United States, due to pledges to reduce waste among food conglomerates seeking approval from increasingly environmentally-conscious consumers and regulators, combined with the volatile prices of fish meal and other feed directing producers to seek alternatives (Table 7).

\section{Legal regulations}

Closely tied with food safety and issues of supply is food regulation (Maurer et al., 2016). Areas without traditional histories of entomophagy and with food policies that prioritize risk avoidance, namely Europe (Knowles et al., 2007; Siegrist, 2007; Vos, 2000; Laurenza and Carreño, 2015), have more stringent rules about insects as a "novel food" that must be addressed before insects can be marketed as human food (European Parliament and the Council of the European Union (Regulation, 2015). A search of FAOLEX, the United Nations' Food and Agriculture Organization's publically available database on food regulations worldwide, has at this point a single entry that specifically mentions black soldier fly. Dating to May 2017, the regulation (European Commission. Regulation, 2017) identifies seven insect species "currently reared in the Union", including Hermetia illucens that fulfill the safety conditions for insect production for farmed and pet animal feed. Namely: "these should not be pathogenic or have other adverse effects on plant, animal or human health; they should not be recognized as vectors of human, animal or plant pathogens and they should not be protected or defined as invasive alien species." They also place restrictions on the substrates fed to BSFL or these other species. 
Table.1 Comparison of nutritional value of black soldier fly larvae meals vis-à-vis conventional meal

\begin{tabular}{|l|c|c|c|}
\hline $\begin{array}{c}\text { Constituents } \\
(\% \text { in DM) }\end{array}$ & BSF Larvae & Fish meal & Soy meal \\
\hline Crudeprotein & 56.9 & 70.6 & 51.8 \\
\hline Lipid & 26.0 & 9.9 & 2.0 \\
\hline Calcium & 7.56 & 4.34 & 0.39 \\
\hline Phosphorus & 0.90 & 2.79 & 0.69 \\
\hline Ca:P ratio & 8.4 & 1.56 & 0.57 \\
\hline
\end{tabular}

(Source: Makkar et al., 2014)

Table.2 Amino acid composition (g/16 g nitrogen) of Black Soldier Fly larvae meals vis-à-vis conventional meal

\begin{tabular}{|c|c|c|c|}
\hline Amino acids & BSF Larvae & Fishmeal & Soymeal \\
\hline \multicolumn{4}{|c|}{ Essential } \\
\hline Methionine & 2.1 & 2.7 & 1.32 \\
\hline Cystine & 0.1 & 0.8 & 1.38 \\
\hline Valine & 8.2 & 4.9 & 4.50 \\
\hline Isoleucine & 5.1 & 4.2 & 4.16 \\
\hline Leucine & 7.9 & 7.2 & 7.58 \\
\hline Phenylalanine & 5.2 & 3.9 & 5.16 \\
\hline Tyrosine & 6.9 & 3.1 & 3.35 \\
\hline Histidine & 3.0 & 2.4 & 3.06 \\
\hline Lysine & 6.6 & 7.5 & 6.18 \\
\hline Threonine & 3.7 & 4.1 & 3.78 \\
\hline Tryptophan & 0.5 & 1.0 & 1.36 \\
\hline \multicolumn{4}{|c|}{ Non-essential } \\
\hline Serine & 3.1 & 3.9 & 5.18 \\
\hline Arginine & 5.6 & 6.2 & 7.64 \\
\hline Glutamicacid & 10.9 & 12.6 & 19.92 \\
\hline Aspartic acid & 11.0 & 9.1 & 14.14 \\
\hline Proline & 6.6 & 4.2 & 5.99 \\
\hline Glycine & 5.7 & 6.4 & 4.52 \\
\hline Alanine & 7.7 & 6.3 & 4.54 \\
\hline
\end{tabular}

(Source: Makkar et al., 2014)

Table.3 Mineral composition of BSF larvae

\begin{tabular}{|l|c|}
\hline \multicolumn{1}{|c|}{ Mineral } & Mean value \\
\hline Calcium & $75.6 \mathrm{~g} / \mathrm{kg}$ \\
\hline Phosphorus & $9.0 \mathrm{~g} / \mathrm{kg}$ \\
\hline Potassium & $6.9 \mathrm{~g} / \mathrm{kg}$ \\
\hline Sodium & $1.3 \mathrm{~g} / \mathrm{kg}$ \\
\hline Magnesium & $3.9 \mathrm{~g} / \mathrm{kg}$ \\
\hline Iron & $1.37 \mathrm{~g} / \mathrm{kg}$ \\
\hline Manganese & $246 \mathrm{mg} / \mathrm{kg}$ \\
\hline Zinc & $108 \mathrm{mg} / \mathrm{kg}$ \\
\hline Copper & $6 \mathrm{mg} / \mathrm{kg}$ \\
\hline
\end{tabular}

(Source: Newton et al., 1977) 
Table.4 Facility required for BSF processing

\begin{tabular}{|l|l|}
\hline BSF rearing unit & $\begin{array}{l}\text { This ensures that a reliable and consistent amount of small larvae } \\
\text { (called 5-DOL) is always available to inoculate the daily amount } \\
\text { of bio-waste that is received for processing at the treatment } \\
\text { facility. A certain number of larvae hatchlings are, however, kept } \\
\text { in the rearing unit to ensure a stable breeding population. }\end{array}$ \\
\hline $\begin{array}{l}\text { Waste receiving and } \\
\text { pre-processing unit }\end{array}$ & $\begin{array}{l}\text { It is critical that the waste received at the facility is suitable for } \\
\text { feeding to the larvae. A first step involves a control of the waste } \\
\text { to ensure it contains no hazardous materials and no inorganic } \\
\text { substances. Further steps then involve a reduction of the waste } \\
\text { particle size, a dewatering of the waste if it has too high moisture } \\
\text { and/or a blending of different organic waste types to create a } \\
\text { suitable balanced diet and moisture (70-80\%) for the larvae. }\end{array}$ \\
\hline $\begin{array}{l}\text { BSF waste treatment } \\
\text { unit }\end{array}$ & $\begin{array}{l}\text { This is where the rearing unit are fed with bio-waste in containers } \\
\text { called "larveros". } \\
\text { Here, the young larvae feed on the bio-waste, grow into large } \\
\text { larvae and, thus, process and reduce the waste. }\end{array}$ \\
\hline $\begin{array}{l}\text { Product harvesting } \\
\text { unit }\end{array}$ & $\begin{array}{l}\text { Shortly before turning into prepupae, the larvae are harvested } \\
\text { from the larva. The waste residue itself is also a product of value. }\end{array}$ \\
\hline $\begin{array}{l}\text { Post-treatment unit } \\
\text { (larvae refining and } \\
\text { residue processing) }\end{array}$ & $\begin{array}{l}\text { Both products, larvae and residue, can be further processed if } \\
\text { required by the local market demand. We call this "product } \\
\text { refining". Typically, a first step will be to kill the larvae. Other } \\
\text { steps of larvae refinement can be to freeze or dry the larvae, or to } \\
\text { separate larvae oil from larvae protein. } \\
\text { A typical step for residue refinement is composting or feeding the } \\
\text { residue into a biogas digester for fuel production. }\end{array}$ \\
\hline
\end{tabular}

Table.5 Optimal environmental conditions and food sources

\begin{tabular}{|l|l|}
\hline Warm climate: & $\begin{array}{l}\text { The ideal temperature is between } 24 \text { and } 30^{\circ} \mathrm{C} \text {. If too hot, the } \\
\text { larvae will crawl away from the food in search of a cooler } \\
\text { location. If too cold, the larvae will slow down their } \\
\text { metabolism, eat less and develop slower. }\end{array}$ \\
\hline Shaded environment: & $\begin{array}{l}\text { Larvae avoid light and will always search for a shaded } \\
\text { environment, away from sunlight. If their food source is } \\
\text { exposed to light, they will move deeper into the layer of food } \\
\text { to escape the light. }\end{array}$ \\
\hline Water content of the food: & $\begin{array}{l}\text { The food source has to be quite moist with a water content } \\
\text { between 60\% and 90\% so that the larvae can ingest the } \\
\text { substance. }\end{array}$ \\
\hline the food: & $\begin{array}{l}\text { Substrates rich in protein and easily available carbohydrates } \\
\text { result in good larval growth. Ongoing research indicates that } \\
\text { waste may be more easily consumed by the larvae if it has } \\
\text { already undergone some bacterial or fungal decomposition } \\
\text { process. }\end{array}$ \\
\hline Particle size of the food: & $\begin{array}{l}\text { As the larvae have no chewing mouthparts, access to nutrients } \\
\text { is easier if the substrate comes in small pieces or even in a } \\
\text { liquid or pasty form. }\end{array}$ \\
\hline
\end{tabular}


Table.6 Steps in Production

\begin{tabular}{|c|c|}
\hline Step-1 & Hang a clean love cage onto its hanger using the loops. \\
\hline Step-2 & Measure weight of the love cage with hanger \\
\hline Step-3 & Attach the hanger onto the mobile frame using the long stick and fasten it at the bottom \\
\hline Step-4 & $\begin{array}{l}\text { Move the mobile frame with the attached love cage to the first dark cage and connect the } \\
\text { two tunnels of the cages, using four binder clips. Turn on the light which is attached to the } \\
\text { mobile frame as soon as the love cage is connected to the dark cage. Gently shake the cage } \\
\text { to rouse the flies. }\end{array}$ \\
\hline Step-5 & $\begin{array}{l}\text { After } 30 \text { minutes, disconnect and close the tunnel, measure weight of love cage and } \\
\text { hanger and move the same love cage to the next dark cage. Repeat the same process of } \\
\text { connecting, disconnecting and weighing after } 30 \text { minutes. Repeat this for all dark cages } \\
\text { with emerged flies }\end{array}$ \\
\hline Step-6 & $\begin{array}{l}\text { Disconnect the love cage from the last dark cage and turn off the light. Close the tunnels } \\
\text { with a rope }\end{array}$ \\
\hline Step-7 & $\begin{array}{l}\text { Now, the love cage contains all the freshly emerged flies from the dark cages. Measure the } \\
\text { weight of the love cage with hanger again. The difference to the empty love cage } \\
\text { measured at the beginning will correspond to the mass (grams) of flies in the love cage. If } \\
\text { you collect } 20 \text { flies and measure their total weight and divide by } 20 \text {, you will have an } \\
\text { average weight of one fly. You can use the mass of flies and divide by the average weight } \\
\text { of one fly to obtain the number of flies in the love cage }\end{array}$ \\
\hline Step-8 & $\begin{array}{l}\text { Move the love cage with its hanger to the love cage table using the long stick with a hook } \\
\text { and hang it into the love cage table }\end{array}$ \\
\hline Step-9 & $\begin{array}{l}\text { Prepare attractant container: fill an empty attractant container with } 100 \text { grams of dead flies } \\
\text { from an old love cage, } 200 \text { grams of residue from the nursery containers, } 200 \text { grams of } \\
\text { residue from the old attractant container and one litre of fermenting fruit water (if no } \\
\text { fermenting fruit water is available, use regular water). Mix thoroughly }\end{array}$ \\
\hline Step-10 & $\begin{array}{l}\text { Prepare } 10 \text { clean eggies: Take clean wooden sheets and separate those between the sheets } \\
\text { with pushpins and sheets without pushpins (see also Step 5). The pushpins will create a } \\
\text { small gap (1-2mm) between the wooden sheets. Build up the egg media alternating } \\
\text { between a sheet with and without pushpins. The sheets are held together by two rubber } \\
\text { bands on both ends of the bundle. Prepare } 10 \text { of these bundles (eggies) for each love cage }\end{array}$ \\
\hline Step-11 & $\begin{array}{l}\text { Prepare water bowl: Fill a clean container with tap water until it is almost full. Take the lid } \\
\text { and a clean cotton cloth and push the cloth on both side through the incision slits made } \\
\text { into the lid. The towel should lie flat on top of the lid, while its ends pass through the } \\
\text { incision slits and are immersed in the water in the container below the lid. Sprinkle the } \\
\text { towel with water }\end{array}$ \\
\hline Step-12 & $\begin{array}{l}\text { Open the love cage with the zipper. Pay attention to avoid flies escaping from the love } \\
\text { cage. Place the attractant containers into the love cage and then place the } 10 \text { clean eggies } \\
\text { over the attractant container. Cover the attractant container and the eggies with the } \\
\text { shading basket placed upside down onto four small pedestals (e.g. binder clips which keep } \\
\text { the shading basket away from the surface to avoid egg laying underneath). Finally, place } \\
\text { the water bowl with towel onto the shading basket and close the love cage }\end{array}$ \\
\hline Step-13 & $\begin{array}{l}\text { After closing the love cage, add a sticker on the table next to the cage labelling the date of } \\
\text { placement }\end{array}$ \\
\hline
\end{tabular}


Table.7 Difference between BSF and worm composting

\begin{tabular}{|c|c|c|c|}
\hline Sr. No & $\begin{array}{l}\text { Characteristics } / \mathbf{P} \\
\text { arameter }\end{array}$ & BSF & Worm composting \\
\hline 1 & Raw material & $\begin{array}{l}\text { Any organic matter (bio- } \\
\text { waste/slaughter house waste/Egg } \\
\text { shells/any manure etc.) High } \\
\text { moisture products even more than } \\
80 \% \text { moisture content }\end{array}$ & $\begin{array}{l}\text { Consume only the } \\
\text { bacteria generated by } \\
\text { the decaying plant } \\
\text { materials }\end{array}$ \\
\hline 2 & Temperature & $\begin{array}{l}\text { Best results } 25-35^{\circ} \mathrm{C} \text { (tolerate } \\
\text { even upto } 40^{\circ} \mathrm{C} \text { ) more suitable in } \\
\text { Indian conditions }\end{array}$ & $\begin{array}{l}\text { Best results } \\
10-15^{\circ} \mathrm{C} \text {, dampness }\end{array}$ \\
\hline 3 & Humidity & Low/even dry & $\begin{array}{l}\text { High humidity } \\
85^{\circ} \mathrm{C}\end{array}$ \\
\hline 4 & Process efficiency & $\begin{array}{l}\text { Fat } 20 \% \text { digestion requires only } \\
24 \mathrm{hr} \text { also known as Accelerator }\end{array}$ & $\begin{array}{l}\text { Slow process } \\
\text { Initially you have to } \\
\text { decay the plant } \\
\text { material for } 20 \text { days } \\
\text { by adding cow dung } \\
\text { etc. }\end{array}$ \\
\hline 5 & $\begin{array}{l}\text { Nutritive value as } \\
\text { feed }\end{array}$ & $\begin{array}{l}\text { BSF larvae have } 35 \% \text { protein, } \\
\text { Good source of energy and can } \\
\text { fulfil the requirement of Essential } \\
\text { amino acids for poultry feed, } \\
\text { easily digestible, Further these kill } \\
\text { salmonella, so problem of } \\
\text { Salmonellosis in poultry can } \\
\text { reduced }\end{array}$ & No such benefit \\
\hline 6 & Quality of product & Free from bad odour, smell & $\begin{array}{l}\text { Free from smell and } \\
\text { odour }\end{array}$ \\
\hline 7 & Biogas & $\begin{array}{l}\text { Residues can be utilized in biogas } \\
\text { plant }\end{array}$ & Cannot utilized \\
\hline 8 & $\begin{array}{l}\text { Nutritive value of } \\
\text { compost }\end{array}$ & $\begin{array}{l}\text { Depend on the type of raw } \\
\text { material. It provide much higher } \\
\text { assimilated nitrogen the } \\
\text { vermicompost }\end{array}$ & $\begin{array}{l}\text { Av. Organic carbon: } \\
\text { 9.5-17.98\% } \\
\text { Nitrogen: } \\
0.5-1.5 \% \\
\text { Phosphorous } \\
0.1-0.3 \%\end{array}$ \\
\hline 9 & $\begin{array}{l}\text { Economics/Cost } \\
\text { of production }\end{array}$ & $\begin{array}{l}\text { Cost effective lower period, } \\
\text { initially availability is a problem } \\
\text { however no sophisticated } \\
\text { machinery nor skilled labour, } \\
\text { process can be completed in 3-5 } \\
\text { days. }\end{array}$ & $\begin{array}{l}\text { Cost effective, } \\
\text { Commonly used in } \\
\text { India so availability of } \\
\text { worms is not a } \\
\text { problem, but process } \\
\text { takes 45-60 days. }\end{array}$ \\
\hline
\end{tabular}

\section{Equipments required}

One love cage made of sturdy mosquito netting with loops at each corners, a long zipper opening and a central round tunnel opening. This is suitable for 6,000-10,000 flies

One hanger per love cage 
Two attractant containers per love cage

One shading basket (slightly larger basket than attractant container) with four small pedestals.

One water bowl with lid per love cage. Make two incision slits into the lid at both sides. The slits should be long and wide enough for a cotton cloth to pass through.

One cotton cloth (towel) per love cage

Ten egg media units (eggies) per love cage.

One mobile frame (with attached electrical light) (see Blue print 2). One can be used to serve several love cages

A stick (approx. 2m) with a hook at the end

Four ant traps per love cage table. The containers should always contain water. The love cage table legs are placed into these containers.

One love cage table with a frame which is large enough for three love cages. The frame should be as high as the love cage so that the bottom of the cage rests on the table (see Blue print 3).

Eight binder clips to attach the dark cage's transfer tunnel to the love cage and to form the pedestals of the shading basket.

The substrates must contain "products of nonanimal origin" or a limited set of animal products that includes fishmeal, rendered fats, blood and gelatin from non-ruminants, milk, eggs, honey, etc. Flesh is not listed, and manure, "catering waste" (human food waste), and "other waste" are explicitly excluded (European Commission. Regulation, 2017). These restrictions eliminate the risk of prion contamination of the BSFL, but greatly limit its usage to close nutrient loops.

In the United States of America, animal feed is considered a "food" and should be regulated by the Food and Drug Administration (FDA); however, the FDA has an official Memorandum of Understanding with the Association of American Feed
Control Officers (AAFCO) for all regulations regarding animal feed (Klonick, 2017). The FDA and AAFCO would regulate BSFL production, packaging, Labeling, distribution, sale, import, and export for direct human and animal consumption respectively.

In August 2016, AAFCO approved the dried larvae of Hermetia illucens "that has been raised on a feedstock composted exclusively of feed grade materials (and which) must contain not less than $34 \%$ crude protein and $32 \%$ fat on an as-fed basis" for use in feeding salmonid fishes (Association of American Feed Control Officials Reports, 2016). At this time, therefore, BSFL cannot be reared on non-feed grade substrates or fed to nonsalmonids. Rearing BSFL on chicken manure and feeding them to fish or chickens or humans is thus not allowed in the USA at this time. Requiring feed-grade substrates for BSFL greatly reduces their environmental benefit; and the protein and fat floors, which were stipulated to ensure consistent product, further limit the types of feed suitable for the larvae and, therefore, their environmental benefit (Klonick, 2017). The authors regrettably cannot include information on food regulations, whether they reference $\mathrm{H}$. illuscens or not, for all other nations.

Regarding international bodies, insects are not listed in the Codex Alimentarius, a United Nations document on what is considered "food" that informs much global food regulatory policy, except as impurities that contaminate food (Van Huis, 2013). This is a problem in the USA as well, where insects are described as a "defect" that can only be found in foods up to a certain point, but not explicitly stated as food (FDA Handbook, 2010). Note that insects are currently sold in the USA and other nations as novelty foods for humans, with the unstated understanding that if the food is supposed to contain insects, then the insects are not a defect. Still, the 
legal perception of insects as a contaminant and not a food and the general human perception of insects as unwanted in the food are both barriers to BSFL or any other insect being normalized as food (Shelomi, 2015).

In conclusion, the ability of black soldier fly larvae to convert low value organic waste products into a high value feedstuff accessible not only to carps, but also to carnivorous fish may limit the need for fish meal and fish oil in the aquaculture industry.

BSFL are edible, nutritious (especially when defatted), and can theoretically be reared more sustainably than extant farmed insects (and, therefore, extant farmed animals) pending further development of large-scale bio refineries. This makes them a potential protein source for humans both in the future and in the developing world. BSF Larvae they are commonly used in household and manure composting in western countries since long time. The rearing of BSF is easier in India as larvae flourish more in tropical environment than in colder one, hence composting using BSFL should be recommended in India as well.

\section{References}

Arango Gutierrez, G. P., Vergara Ruiz, R. A., and Mejia Velez, H. 2004. Compositional, microbiological and protein digestibility analysis of larval meal of Hermetia illucens (Diptera: Stratiomyidae) at AngelopolisAntioquia, Colombia. Revista Facultad Nacional de Agronomia Medellin, 57 (2): 2491-2499

Association of American Feed Control Officials. In Proceedings of the AAFCO Annual Meeting Agenda and Committee Reports. 2016. Pittsburgh, PA, USA, 31 July-3 August 2016; AAFCO: Pittsburgh, PA, USA,; p. 112
Diener, S., Zurbrügg, C.Roa Gutiérrez, F. Nguyen Dang Hong Morel, A., Koottatep, T. and Tockner, K. 2011. Black soldier fly larvae for organic waste treatment - prospects and constraints. Waste Safe. (2011). 2nd Int. Conf. on Solid Waste Management in the Developing Countries, 13-15 February 2011, Khulna, Bangladesh, 52-59

European Commission. Regulation (EU) 2017/893 of 24 May. 2017. Amending Annexes I and IV to Regulation (EC) No 999/2001 of the European Parliament and of the Council and Annexes X, XIV and XV to Commission Regulation (EU) No $142 / 2011$ as regards the provisions on processed animal protein.

European Parliament and the Council of the European Union. Regulation (EU) 2015/2283 of the European Parliament and of the Council on novel foods. 2015. Amending regulation (EU) No $1169 / 2011$ of the European Parliament and of the Council and repealing Regulation (EC) No 258/97 of the European Parliament and of the Council and Commission Regulation (EC) No 1852/2001

Food and Drug Administration. Defect levels handbook. 2010. In The Food Defect Action Levels: Levels Of Natural or Unavoidable Defects in Foods That Present no Health Hazards for Humans; Center for Food Safety and Applied Nutrition, Ed., US Food and Drug Administration: Washington, DC, USA.

Gennard, D. E. 2012. Forensic Entomology: An Introduction, Wiley, Chicester

Gustavsson, J., Cederberg, C., Sonesson, U., Van Otterdijk, R. and Meybeck, A. 2011. Global Food Losses and Food Waste. Rome: Food and Agriculture Organization of the United Nations. 
Available at: http://www.fao.org/file admin/user_upload/ags/publications/ GFL_web.pdf

Hardouin, J. and Mahoux, G. 2003. Zootechnied' insectes Elevageetutilisation au bénéfice de l'hommeet de certainsanimaux. Bureau pour l'Echangeet la Distribution de l'Informationsur le Mini-élevage (BEDIM), $164 \mathrm{p}$

Klonick, A. Bug ideas. 2017. Assessing the market potential and regulation of insects. Master's Thesis, Duke University, Durham, NC, USA.

Knowles, T., Moody, R., McEachern, M.G. 2007. European food scares and their impact on EU food policy. Br. Food J., 109, 43-67.

Laurenza, E.C., Carreño, I. 2015. Edible insects and insect-based products in the EU: Safety assessments, legal loopholes and business opportunities. Eur. J. Risk Regul. 6, 288-292.

Leclercq, M. 1997. A propos de Hermetia illucens (Linnaeus, 1758) (Soldier fly) (Diptera Stratiomyidae: Hermetiinae). Bull. Annls. Soc. Belge Ent., 133: 275-282

Li, Q., Zheng, L., Qiu, N., Cai, H., Tomberlin, J. K. and $\mathrm{Yu}, \mathrm{Z}$. 2011. Bioconversion of dairy manure by black soldier fly (Diptera: Stratiomyidae) for biodiesel and sugar production. Waste Management Research, 31:1316-20

Makkar, H. P.S., Tran,G, Heuzé V. and Ankers, P. 2014. State-of-the-art on use of insects as animal feed. Animal Feed Science and Technology, 197, 133

Maurer, V., Holinger, M., Amsler, Z., Früh, B., Wohlfahrt, J., Stamer, A., Leiber, F. 2016. Replacement of soybean cake by Hermetia illucens meal in diets for layers. J. Insects Food Feed, 2, 83-90.

Newton, G. L., Booram, C. V., Barker, R.W. and Hale, O. M. 1977. Dried Hermetia illucens larvae meal as a supplement for swine. Journal of Animal Sciences, 44 (3): 395-400.

Newton, G. L., Sheppard, D. C. and Burtle, G. 2008. Black soldier fly prepupae: a compelling alternative to fi sh meal and fi sh oil. Public comment on alternative feeds for aquaculture, NOAA 15/11//2007 - 29/2/2008

Sealey, W. M., Gaylord, T. G., Barrows, F. T., Tomberlin, J. K., Mcguire, M. A., Ross, C. and St-Hilaire, S. 2011. Sensory analysis of rainbow trout, Oncorhynchusmykiss, fed enriched Blacksoldierfl y prepupae, Hermetia illucens. Journal of World Aquaculture Society, 42: 34-45

Shelomi, M. 2015. Why we still don't eat insects: Assessing entomophagy promotion through a diffusion of innovations framework. Trends Food Sci. Technol., 45, 311-318.

Sheppard, D. C., Larry Newton, G., Thompson, S. A. and Savage, S. 1994. A value added manure management system using the black soldier fly. Bio resource Technology, 50:275-279.

Siegrist, M. 2008. Factors influencing public acceptance of innovative food technologies and products. Trends Food Sci. Technol., 19, 603-608.

St-Hilaire, S., Cranfill, K., Mcguire, M. A., Mosley, E. E., Tomberlin, J. K., Newton, L., Sealey, W., Sheppard, C. and Irving, S. 2007. Fish off al recycling by the black soldier fly produces a foodstuff high in omega3 fatty acids. Journal of World Aquaculture Society, 38: 309-313.

Van Huis, A., Van Itterbeeck, J., Klunder, H., Mertens, E., Halloran, A., Muir, G. and Vantomme, P. 2013. Edible insects - Future prospects for food and feed security. FAO Forestry Paper 171. 
Van Huis, A., van Itterbeeck, J., Klunder, H., Mertens, E., Halloran, A., Muir, G., Vantomme, P. 2013. Edible Insects: Future Prospects for Food and Feed Security; Food and agriculture organization of the United Nations (FAO): Rome, Italy. Pp. 171.

Vos, E. 2000. EU food safety regulation in the aftermath of the BSE crisis. J. Consum. Policy, 23, 227-255

\section{How to cite this article:}

Rindhe, S.N., Manish Kumar Chatli, R.V. Wagh, Amanpreet Kaur, Nitin Mehta, Pavan Kumar and Malav, O.P. 2019. Black Soldier Fly: A New Vista for Waste Management and Animal Feed. Int.J.Curr.Microbiol.App.Sci. 8(01): 1329-1342.

doi: https://doi.org/10.20546/ijcmas.2019.801.142 